\title{
Rule 11 and the Policing of Access to the Courts after Professional Real Estate Investors
}

\author{
Thies Kölln†
}

The Noerr-Pennington doctrine, developed in a series of Supreme Court decisions, exempts parties from antitrust liability under the Clayton Act ${ }^{1}$ and Sherman Act $\$ \S 1$ and $2^{2}$ when their alleged anticompetitive behavior involves petitioning any branch of the government. Under a narrow exception, the doctrine does not apply to "sham" petitions, that is, petitions that seek protection under Noerr-Pennington but are actually "nothing more than ... attempt[s] to interfere directly with the business relationships of a competitor." Until recently, however, the Supreme Court had not definitively set the standard for determining when a lawsuit or other petitioning activity constitutes a sham. The Court resolved this question, at least with respect to lawsuits, in Professional Real Estate Investors, Inc. $v$ Columbia Pictures Industries, Inc. ${ }^{4}$ A suit may be deemed a sham under the exception to Noerr-Pennington only if it is objectively baseless, regardless of the filing party's subjective intent. ${ }^{5}$

By answering the question in this way, however, the Professional Real Estate Investors holding creates a tension between the sham exception to the Noerr-Pennington doctrine and Rule 11 of the Federal Rules of Civil Procedure, which instructs judges to examine both the objective merits of a party's suit and the party's subjective intent in bringing the suit. This tension raises two significant issues. First, may a court properly sanction a party under Rule 11 when the party brings an antitrust suit that is not a sham for the purposes of Noerr-Pennington? Second, and potentially more significant, what implications does the Court's endorsement of the objective-baselessness standard in the antitrust

$\dagger$ A.B. 1992, Dartmouth College; J.D. Candidate 1995, The University of Chicago.

138 Stat 730 (1914), codified at 15 USC $\$ \S 12-21$ (1988 \& Supp 1992).

226 Stat 209 (1890), codified at 15 USC $\S \S 1,2$ (1988 \& Supp 1992).

3 Eastern Railroad Presidents Conference v Noerr Motor Freight, Inc., 365 US 127, 144 (1961).

1113 S Ct 1920 (1993).

5 Id at 1926, 1928. 
context have for Rule 11 jurisprudence, particularly to the extent that Rule 11 rests on similar rationales for sanctioning certain forms of behavior?

This Comment addresses the tension between Professional Real Estate Investors and Rule 11 and argues that, at least in some contexts, a new interpretation of Rule 11 will be necessary to resolve the inconsistencies between these areas of the law. Sections I and II trace, respectively, the development of NoerrPennington immunity and Rule 11 sanctions based on improper subjective intent. Section III analyzes the doctrinal tension between the sham exception to Noerr-Pennington immunity and Rule 11, and suggests that Rule 11 must be curtailed in the antitrust context. This Comment argues that reinterpreting Rule 11 is both necessary in light of the Court's recent decision in Professional Real Estate Investors and justified by other considerations inherent in sanctioning mechanisms in antitrust law. Finally, Section IV examines the implications of Professional Real Estate Investors for Rule 11 sanctions in other contexts. This Comment concludes that the same considerations that favor limiting Rule 11 sanctions in antitrust proceedings are equally applicable whenever courts perform a function similar to the economic regulation of large and complex business enterprises.

\section{The Development of the NoERR-PENNINGTON DOCTRINE}

A. Noerr: The Origin of the Doctrine

Eastern Railroad Presidents Conference $v$ Noerr Motor Freight, Inc. involved a suit by a group of forty-one trucking companies against twenty-four eastern railroads and an association of their presidents. ${ }^{6}$ The trucking companies charged that the railroads were attempting to monopolize the long-haul freight business and restrain competition in violation of the Sherman Act. ${ }^{7}$ The action complained of was a publicity campaign by the railroads using third parties to turn public opinion against the interstate trucking industry, influence the Pennsylvania legislature to pass laws that would economically damage the trucking industry, and persuade officials to step up the enforcement of various regulations relating to trucking, all in order to hurt the truckers as competitors in violation of the Sherman Act. ${ }^{8}$ The

6 365 US 127, 129 (1961).

7 Id at 129.

s Id at 129-30. The truckers were especially upset over the railroad's "third-party 
complaint charged that these actions were "vicious, corrupt, and fraudulent."

The Supreme Court declined to find a Sherman Act violation on these facts. There were two bases for this decision: Congress's intent in passing the Sherman Act, and the First Amendment implications of sanctioning political activity (in this case, lobbying a legislature). ${ }^{10}$ With respect to the first basis, the Court acknowledged that such joint lobbying efforts "could perhaps . . . be brought within the general proscription of 'combination $[s]$. . . in restraint of trade," but found that they were not the type of activities with which the Sherman Act was normally concerned. ${ }^{11}$ Further, to sanction petitioning activity when the petitioning results in a restraint of trade would "impute to the Sherman Act a purpose to regulate, not business activity, but political activity, a purpose which would have no basis whatever in the legislative history of that Act."12 This basis of Noerr shows the Court's desire to protect the proper functioning of government by restricting some methods of petitioning the government.

The second foundation for Noerr was the First Amendment right to petition the government. ${ }^{13}$ The Court did not expressly rule on the constitutionality of construing the Sherman Act to prohibit petitioning, but nonetheless stated that such an interpretation of the Act "would raise important constitutional questions. The right of petition is one of the freedoms protected by the Bill of Rights, and we cannot, of course, lightly impute to Congress an intent to invade these freedoms."14

technique," which made the publicity materials appear to come from independent sources when, in fact, the materials had been "largely prepared . . . and paid for by the railroads."

- Id at 129. The background of this suit has been described as "a factual context that reeked with deception, malice, misrepresentation and outright fraud." Maxwell M. Blecher and Joel R. Bennett, Litigation as an Integral Part of a Scheme to Create or Maintain an Illegal Monopoly, 26 Mercer L Rev 479, 483 (1975).

${ }_{10}$ Noerr, 365 US 137-38. For a discussion of the relative importance of these two factors and the principles underlying them, see Robert H. Bork, The Antitrust Paradox: A Policy at War with Itself 350-51 (Free Press, 2d ed 1993) (originally published in 1978); Daniel R. Fischel, Antitrust Liability for Attempts to Influence Government Action: The Basis and Limits of the Noerr-Pennington Doctrine, 45 U Chi L Rev 80, 94-104 (1977); Milton Handler and Richard A. De Sevo, The Noerr Doctrine and Its Sham Exception, 6 Cardozo L Rev 1, 3-7 (1984); James D. Hurwitz, Abuse of Governmental Processes, the First Amendment, and the Boundaries of Noerr, 74 Georgetown L J 65, 78-80 (1985).

i1 365 US at 136, quoting the Sherman Act, 15 USC $\$ 1$.

12365 US at 137.

13 "Congress shall make no law ... abridging... the right of the people... to petition the Government for a redress of grievances." US Const, Amend I.

14 365 US at 138. The articulation of these two rationales left the lower courts unsure 
These two rationales affect the general applicability of the Noerr doctrine, in its later form, to other areas of the law, such as Rule 11. If Noerr is read as a case about the proper functioning of government institutions and processes, one aspect of which would be judicially supervised economic regulation, then arguments from the Noerr line of cases may be analogized to other situations that implicate similar governmental functions. However, if Noerr is about protecting the right to petition, its implications may be more far-reaching. Reading Noerr as a constitutional prohibition of certain restrictions on the right to petition would require a reexamination of restrictions on litigation in all contexts. $^{15}$

The other significant element of Noerr was its sham exception. Instead of granting antitrust defendants an impenetrable shield against liability, the Court foresaw potential cases in which petitioning activity could be an antitrust violation. In a case where the petitioning "is a mere sham to cover what is actually nothing more than an attempt to interfere directly with the business relationships of a competitor [ ] the application of the Sherman Act would be justified."16 The Court also observed that the railroads' effort to influence legislation not only seemed genuine, but had been "highly successful."17 However, these statements represented the extent of the Court's discussion of a possible exception to the rule it had just laid down. The Court failed to articulate any standards for distinguishing sham petitioning from legitimate efforts to influence governmental bodies, although the decision appears to express a preference for objective determinations of motive. In evaluating the truckers' claim that the railroad presidents' sole motive for the publicity campaign was to destroy the trucking industry as a competitor-an essen-

whether they should protect some degree of a right to petition or, given the intent of the Sherman Act, simply refrain from interfering inappropriately with the political process. See generally Handler and De Sevo, 6 Cardozo L Rev 1 (cited in note 10). See also Stanley E. Crawford, Jr. and Andy A. Tschoepe II, The Erosion of the Noerr-Pennington Immunity, 13 St. Mary's L J 291, 306-26 (1981); Hurwitz, 74 Georgetown L J at 79-80 (cited in note 10 ).

${ }_{15}$ This reading of Noerr would implicate not only Rule 11 as applied to all types of suits, but also other restrictions on litigation, such as the common law torts of malicious prosecution and abuse of process. For more discussion of these torts, see text accompanying notes 123-24. See generally Note, Limiting the Antitrust Immunity for Concerted Attempts to Influence Courts and Adjudicatory Agencies: Analogies to Malicious Prosecution and Abuse of Process, 86 Harv L Rev 715 (1973); Thomas A. Balmer, Sham Litigation and the Antitrust Laws, 29 Buff L Rev 39, 65-70 (1980).

${ }_{16}$ Noerr, 365 US at 144.

17 Id. 
tial part of the district court's holding in favor of the plaintiffs-the Court stated that it did 'not see how [the defendants' motive], even if adequately supported in the record, could transform conduct otherwise lawful into a violation of the Sherman Act." 18

\section{B. Pennington: Reaffirming Noerr}

The second major Supreme Court case on the antitrust implications of attempts to influence government action was United Mine Workers $v$ Pennington. ${ }^{19}$ In this case, as in many subsequent cases, the antitrust violation was alleged in a counterclaim. ${ }^{20}$ The trustees of the United Mine Workers of America Welfare and Retirement Fund ("UMW") sued the owners of a coal company for overdue royalty payments; the defendants counterclaimed, alleging that the UMW, in conjunction with a group of large coal producers, had lobbied the Secretary of Labor to obtain an unusually high minimum-wage requirement for companies selling coal to the Tennessee Valley Authority. ${ }^{21}$ The Supreme Court held that the UMW's attempt to influence the Secretary of Labor was not an unlawful attempt to restrict trade. ${ }^{22}$

Although the Court did not address the sham exception to the Noerr doctrine, Pennington is significant in two respects. First, the Court affirmed the basic rule laid down by Noerr, that petitioning activity cannot give rise to antitrust liability. The Court failed, however, to clarify the underlying basis of the doctrine, that is, whether the doctrine was grounded in concerns about the proper functioning of government or in the First Amendment. ${ }^{23}$ Second, Pennington, like Noerr, contained dicta rejecting the relevance of intent-and thus favoring an objective test-for determining whether activity is protected from antitrust liability. The Court stated that "Noerr shields from the Sherman Act a concerted effort to influence public officials regardless of intent or purpose" and that "[j]loint efforts to influence public officials do not violate the antitrust laws even though intended to

18 Id at 138-39.

19381 US 657 (1965).

20 For a survey of the different forms in which the Noerr doctrine and the sham exception have been litigated, see Handler and De Sevo, 6 Cardozo L Rev at 26-28 (cited in note 10 ).

${ }^{21}$ Pennington, 381 US at 659-60.

22 Id at 669-70.

${ }^{23}$ See Fischel, $45 \mathrm{U}$ Chi L Rev at 85 (cited in note 10); Crawford and Tschoepe, $13 \mathrm{St}$ Mary's L J at 299 (cited in note 14). 
eliminate competition."24 Admittedly, these statements do not amount to a comprehensive description of which lawsuits will be protected from antitrust liability. Significantly, however, they suggest that the Court preferred to think about antitrust violations in a consequentialist manner, that is, with an eye not to the intent of the parties, but to the outcome of a governmental process.

\section{California Motor Transport: Expanding Noerr Immunity}

The third major decision developing what has come to be known as the Noerr-Pennington doctrine is California Motor Transport Co. $v$ Trucking Unlimited. ${ }^{25}$ In this case between two groups of trucking companies, Trucking Unlimited alleged that California Motor Transport and other large trucking companies had systematically instituted proceedings against Trucking Unlimited in order to hinder Trucking Unlimited's efforts to acquire, transfer, and register operating rights. ${ }^{26}$ California Motor Transport significantly extended Noerr to encompass petitioning activity directed at the judicial branch-that is, lawsuits-yet still left open the question of whether the sham exception should be based on a subjective or an objective test.

In its decision, the Court first reaffirmed Noerr and Pennington, and then held that "[ $t]$ he same philosophy governs the approach of citizens or groups of [citizens] to administrative agencies ... and to courts, the third branch of Government . . . . The right of access to the courts is indeed but one aspect of the right of petition."27 While California Motor Transport relied heavily on the First Amendment basis for Noerr, and can easily be read as an extension of the right of petition to all litigation passing muster under $N o e r r,{ }^{28}$ some language in the decision casts doubt on whether the protection from antitrust liability is coextensive with First Amendment protection. ${ }^{29}$

${ }^{24}$ Pennington, 381 US at 670.

${ }^{25} 404$ US 508 (1972).

26 Id at 509 .

27 Id at 510. This language also for the first time applied the antitrust immunity doctrine to an individual petitioner, as opposed to a group of individuals or other entities engaged in joint petitioning.

${ }^{28}$ See id at 513. See also Fischel, $45 \mathrm{U}$ Chi L Rev at 88 (cited in note 10); Handler and De Sevo, 6 Cardozo L Rev at 10-13 (cited in note 10).

29 "Petitioners, of course, have the right of access to the agencies and courts to be heard on applications sought by competitive highway carriers. That right ... is part of the right of petition protected by the First Amendment. Yet that does not necessarily give them immunity from the antitrust laws." 404 US at 513. 
The central questions still unresolved at this point were the extent of the sham exception and the appropriate test for applying it. The Court did apply the sham exception in this case, concluding that California Motor Transport's suits had "sought to bar their competitors from meaningful access to adjudicatory tribunals and so to usurp the decisionmaking process." ${ }^{30}$ The lawsuits filed by the defendants were alleged to have been instituted "with or without probable cause, and regardless of the merits of the cases." ${ }^{\prime 31}$ One clear result of this holding is that "there is no constitutional right . . . to press baseless claims for the ulterior purpose of wreaking economic injury upon a competitor." ${ }^{\text {"32 }}$ However, the Court also spoke of "a purpose to deprive the competitors of meaningful access to the agencies and courts. ${ }^{33}$ To the extent that this language suggests that intent might be a factor in determining whether the litigation was a sham, it conflicts with Pennington. However, because California Motor Transport's claims failed both the objective and the subjective tests, it is not clear how the Court would have resolved the case had the claims been well grounded in fact and law.

\section{The Objective Baselessness Test}

In the wake of California Motor Transport, lower courts were forced to develop their own standards by which to judge what constituted sham litigation. Later Supreme Court decisions did contain dicta supporting an objective test, but the precise issue, seen most clearly in the conflicting statements in California Motor Transport, remained unresolved until Professional Real Estate Investors.

\section{The Supreme Court antitrust cases.}

Four significant cases decided after California Motor Transport point generally, though not unanimously, toward an objective standard for distinguishing sham suits from legitimate litigation. In one case, a minority of justices suggested that subjective

30 Id at 512.

31 Id.

32 Bork, Antitrust Paradox at 359 (cited in note 10). The Court spoke of "a pattern of baseless, repetitive claims [that] may emerge which leads the factfinder to conclude that the administrative and judicial processes have been abused." California Motor Transport, 404 US at 513.

${ }^{33} 404$ US at 512. See also id at 518 (Stewart concurring). 
elements were appropriate, while three decisions clearly showed a tendency to favor objective measures.

In Vendo Co. $v$ Lektro-Vend Corp., a vending machine manufacturer sued a former vending machine manufacturer for breach of a noncompetition agreement that the two parties had entered into as part of an asset purchase. ${ }^{34}$ In response, the defendant filed a counterclaim alleging that the real purpose behind the breach of contract suit was to "harass" and "eliminate" the defendant as a competitor. ${ }^{35}$ The heart of the case was whether a single state-court action could constitute an antitrust violation. The Court's brief discussion of the Noerr-Pennington doctrine and its sham exception consisted of dicta split in its implications for the standard for determining shams. Justice Blackmun's concurring opinion, joined by Chief Justice Burger, implied that a single successful state court proceeding could not constitute an antitrust violation. ${ }^{36}$ Four dissenting Justices, on the other hand, stated that "[t]he mere fact that the Illinois courts concluded that petitioner's state-law claim was meritorious does not disprove the existence of a serious federal antitrust violation."37 This case, along with California Motor Transport, is the furthest the Court has strayed from an objective test of bad-faith sham litigation in the antitrust context. ${ }^{38}$

$\begin{array}{ll}{ }^{34} & 433 \text { US 623, 626-27 (1977). } \\ 35 & \text { Id. } \\ { }_{36} & \text { Blackmun stated: }\end{array}$

Only one state-court proceeding was involved in this case, and it resulted in the considered affirmance by the Illinois Supreme Court of a judgment for more than $\$ 7$ million. In my opinion, therefore, it cannot be said on this record that Vendo was using the state-court proceeding as an anticompetitive device in and of itself.

Id at 645 (Blackmun concurring in the result).

${ }^{37}$ Id at 662 (Stevens dissenting).

38 The dissent's position, if taken to the extreme, may imply that merit is irrelevant to the sham determination. See Note, The Sham Exception to the Noerr-Pennington Doctrine, 11 Hastings Const L Q 329, 341 (1984). See also Walker Process Equipment, Inc. $v$ Food Machinery \& Chemical Corp., 382 US 172, 173-77 (1965) (upholding as a valid antitrust action the counterclaim of a patent infringement defendant that challenged the enforcement of an expired and fraudulently obtained patent as a restraint of trade). Although devoid of references to Noerr or Pennington, Walker Process indicates that lawsuits seeking to enforce invalid or fraudulently obtained patents can be valid bases for antitrust liability. However, because such suits involve both improper intent and objective baselessness, they offer little assistance in answering the questions posed in this Comment. For an analysis of Walker Process and the antitrust implications of fraud and other crimes generally, see Blecher and Bennett, 26 Mercer L Rev at 486-87 (cited in note 9); Michael W. Bien, Litigation as an Antitrust Violation: Conflict Between the First Amendment and the Sherman Act, 16 USF L Rev 41, 81-83 (1981). But see Bork, Antitrust Paradox at 35253 (cited in note 10) (suggesting that Walker Process "took the case outside the exception 
Three other cases decided between California Motor Transport and Professional Real Estate Investors point in the opposite direction. These cases indicate a tendency of the Supreme Court to favor objective tests when applying the Noerr-Pennington doctrine. The first case, following closely on the heels of California Motor Transport, was Otter Tail Power Co. $v$ United States. ${ }^{39}$ In Otter Tail, the defendant power company had attempted to prevent the startup of municipal power systems in areas where its retail distribution franchises had expired. Part of the company's strategy involved instituting lawsuits to prevent the formation of municipal systems. ${ }^{40}$ The District Court originally found Otter Tail's litigation to be an antitrust violation. ${ }^{41}$ But by the time the case reached the Supreme Court, California Motor Transport had been decided, and the case was ultimately remanded for reconsideration in light of the extension of the Noerr doctrine to petitioning courts. ${ }^{42}$ The Court described the implications of its extension of the doctrine in the following terms:

[T] he principle of Noerr may also apply to the use of administrative or judicial processes where the purpose to suppress competition is evidenced by repetitive lawsuits carrying the hallmark of insubstantial claims and thus is within the "mere sham" exception announced in Noerr. ${ }^{43}$

The key term here, of course, is "insubstantial," by which it seems obvious that the Court means "frivolous," and not "for a small amount of money." While this is admittedly only dicta, it both clarifies California Motor Transport and gives another example of the Court's tendency to think along objective lines when engaged in antitrust regulation.

The next case, Allied Tube \& Conduit Corp. v Indian Head, Inc., was not about petitioning the courts. ${ }^{44}$ The original plaintiff, Indian Head, a manufacturer of plastic electrical conduit, brought an antitrust claim against Allied Tube, the largest producer of steel conduit. Indian Head alleged that Allied Tube had influenced the National Fire Protection Association, a private organization that develops product safety standards, to reject a

to Section 2 liability for those who enforce patents, valid or not, in good faith").

39 410 US 366 (1973).

to Id at 368 .

11 United States v Otter Tail Power Co., 331 F Supp 54, 61 (D Minn 1971).

2 Otter Tail, 410 US at 380.

43 Id.

486 US 492 (1988). 
proposal to classify plastic conduit as an approved type of electrical conduit. ${ }^{45}$ The Court denied Noerr-Pennington immunity to Allied Tube's efforts to sway the NFPA, largely because it was a private, non-official body, albeit one whose fire-safety product codes directly influenced state and local governments. ${ }^{46}$ Notwithstanding this holding, the Court noted that Allied's "effort to influence governmental action in this case certainly cannot be characterized as a sham given the actual [success of the plan]."47 Yet the Court declined to protect all successful attempts to influence the government. ${ }^{48}$ Noerr immunity, the Court observed, depends not only on the impact of the anticompetitive activity, "but also on the context and nature of the activity." 49 Allied Tube, however, shows that the Court continued to think about sham findings, at least in some contexts, in an objective, outcome-oriented manner.

City of Columbia $v$ Omni Outdoor Advertising, Inc. is the most recent Supreme Court case to discuss the sham exception yet still leave unresolved the issue of how to identify sham litigation. ${ }^{50}$ In Omni, a suit was brought against an advertising company and a city that had allegedly conspired to restrict billboards by changing zoning ordinances. ${ }^{51}$ The Court made no clear statement supporting either a subjective or an objective test for sham suits, but cited dicta from previous cases, including Noerr, Pennington, and Allied Tube, that point toward an objective

45 Id at 495-97. Electrical conduit is the tubing used to run electrical wires through walls and floors.

46 Id at 501-502.

47 Id at 502 .

48 Id at 503 .

49 Id at 504. Though petitioning of all three branches of government falls under the Noerr-Pennington doctrine, there are differences in the treatment given the various branches. This is a natural result of the different processes and goals of petitioning in these areas. It has been suggested, for example, that the courts are more susceptible to injury from abuse of procedural rules; if true, this would support a clearly defined (and, as this Comment suggests, objective) policing procedure. For a discussion of some of the differences between the three branches with regard to petitioning activity, see Bork, Antitrust Paradox at 359-64 (cited in note 10); Fischel, 45 U Chi L Rev at 104-10 (cited in note 10); Handler and De Sevo, 6 Cardozo L Rev at 18-33 (cited in note 10); Hurwitz, 74 Georgetown L J at 82-93 (cited in note 10); Earl W. Kintner and Joseph P. Bauer, Antitrust Exemptions for Private Requests for Governmental Action: A Critical Analysis of the Noerr-Pennington Doctrine, 17 UC Davis L Rev 549, 570-71 (1984); Note, 11 Hastings Const $L Q$ at 339, 349-50 (cited in note 38) (analyzing statements in California Motor Transport supporting the view that judicial process is more subject to injury from petitioning).

so 490 US 365 (1991).

51 Id at 367-69. 
test. ${ }^{2}$ The Court also noted the difficulty of proving subjective intent in cases of this nature..$^{53}$

\section{The lower courts' responses.}

The circuit courts responded differently to what they perceived as an unclear standard for identifying sham suits, developing three positions in all. At one extreme, some courts held that no meritorious suit could be deemed a sham. Both of the other tests allowed judges to find some meritorious suits to be shams: one viewed success on the merits as merely raising a rebuttable presumption that the suit was not a sham, while the other employed economic analysis to help the court ascertain motive without regard to the underlying merits of a case.

Most courts adopted an objective view and held, either explicitly or implicitly, that successful litigation could never constitute a sham. ${ }^{54}$ Some courts extended this principle to expressly protect suits that "even if ultimately unsuccessful, do not lack a reasonable basis in fact or law. ${ }^{255}$ This approach seems to be a logical extension of the prior Supreme Court cases and, in fact, foreshadows the Professional Real Estate Investors decision. It also received support from academic literature on the NoerrPennington doctrine. ${ }^{56}$

52 Id at $378-82$.

63 Id at 383 .

54 See, for example, Columbia Pictures Industries, Inc. v Redd Horne, Inc., 749 F2d 154, 161 (3d Cir 1984); Eden Hannon \& Co. $v$ Sumitomo Trust \& Banking Co., 914 F2d 556, 564-65 (4th Cir 1990); South Dakota $v$ Kansas City Southern Industries, Inc, 880 F2d 40, 54 (8th Cir 1989); Columbia Pictures Industries, Inc. $v$ Professional Real Estate Investors, Inc., 944 F2d 1525, 1530 (9th Cir 1991), aff'd, Professional Real Estate Investors, Inc. $v$ Columbia Pictures Industries, Inc., $113 \mathrm{~S}$ Ct 1920 (1993); Hydro-Tech Corp. $v$ Sundstrand Corp., 673 F2d 1171, 1175 (10th Cir 1982); McGuire Oil Co. v Mapco, Inc., 958 F2d 1552, 1560 (11th Cir 1992), rev'd on other grounds, 986 F2d 444 (11th Cir 1993); Federal Prescription Service, Inc. v American Pharmaceutical Assoc., 663 F2d 253, 262-63, 265 (DC Cir 1981); Southern Pacific Communications Co. v AT\&T, 556 F Supp 825, 87071 (D DC 1983).

${ }_{65}$ McGuire Oil, 958 F2d at $1560 \mathrm{n}$ 12. See also Opdyke Investment Co. $v$ City of Detroit, 883 F2d 1265, 1273 (6th Cir 1989); First American Title Co. $v$ South Dakota Land Title Assoc., 714 F2d 1439, 1447-48 (8th Cir 1983); Alexander v National Farmers Org., 687 F2d 1173, 1200 (8th Cir 1982). See also Omni Resource Development Corp. v Conoco, Inc., $739 \mathrm{~F} 2 \mathrm{~d} 1412,1414$ (9th $\mathrm{Cir} 1984$ ) (holding a suit obtaining a preliminary injunction not to be a sham, regardless of the final outcome).

${ }^{56}$ See Hurwitz, 74 Georgetown L J at 104-05 (cited in note 10); Handler and De Sevo, 6 Cardozo L Rev at 30-31 (cited in note 10); Kintner and Bauer, 17 UC Davis L Rev at 576-79 (cited in note 49); Note, 86 Harv L Rev at 730-31 (cited in note 15); Note, 11 Hastings Const $L Q$ at 345-46 (cited in note 38). See generally Comment, Meritorious Litigation as a Section 2 Violation-In re Burlington Northern, Inc. Broadens NoerrPennington's Sham Exception, 74 Iowa L Rev 271 (1988). But see Phillip E. Areeda and 
While other courts held that meritorious litigation could be a sham, ${ }^{57}$ their position did not greatly diverge from that of courts employing a more objective test. These cases typically took the view that "when a lawsuit raises a legal issue of genuine substance, it raises a rebuttable presumption that it is a serious attempt to obtain a judgment on the merits instead of a mere sham or harassment." ${ }^{\text {"58 }}$ Although the difference between a purely objective test and a rebuttable presumption may appear slight, it is the key to understanding Professional Real Estate Investors and its implications. Even when courts create a rebuttable presumption against sham litigation for successful cases, it still signifies that courts are willing to investigate the subjective intent of the party that brought the suit. Such an inquiry, by implication, would be even more likely when the litigation is ultimately unsuccessful. While this Comment argues below that considering subjective intent is precisely what the courts should avoid doing, ${ }^{59}$ the important point at present is that the subjective test-which the Supreme Court later rejected-allowed a speculative inquiry for shams that could override the objective evidence of merit which will usually be before the court anyway. ${ }^{60}$

Herbert Hovenkamp, Antitrust Law: An Analysis of Antitrust Principles and Their Application 21 (Little, Brown, Supp 1987) (advocating a "strong presumption, rather than a categorical rule, that successful litigation cannot be a sham"); Bien, 16 USF L Rev at 5657 (cited in note 38) (favoring a test based on a party's subjective intent).

${ }_{57}$ See In re Burlington Northern, Inc., 822 F2d 518, 528 (5th Cir 1987); Associated Radio Service Co. v Page Airways, Inc., 624 F2d 1342, 1358 (5th Cir 1980); Westmac, Inc. v Smith, 797 F2d 313, 318 (6th Cir 1986); Sunergy Communities, Inc. v Aristek Properties, Ltd., 535 F Supp 1327, 1331 (D Colo 1982) ("Success is, in any event, only one factor to consider in determining whether an action is a 'sham."). Some courts have focused on the intent of the party bringing the suit rather than the suit's objective merit, thereby implicitly allowing otherwise meritorious litigation to be judged shams. See Coastal States Marketing, Inc. v Hunt, 694 F2d 1358, 1372 (5th Cir 1983); Greenwood Utilities Commission v Mississippi Power Co., 751 F2d 1484, 1498 n 9 (5th Cir 1985); Mark Aero, Inc. v Trans World Airlines, Inc., 580 F2d 288, 297 (8th Cir 1978); Handgards, Inc. $v$ Ethicon, Inc., 601 F2d 986, 994-96 (9th Cir 1979); Aloha Airlines, Inc. v Hawaiian Airlines, Inc., 349 F Supp 1064, 1065, 1068 (D Hawaii 1972) (holding a valid cause of action was stated although the only allegations were of anticompetitive "intent and purpose").

s8 Westmac, 797 F2d at 318. See also Burlington Northern, 822 F2d at 528 ("[S] uccess on the merits does not necessarily preclude an antitrust plaintiff from proving that the defendant's earlier litigation activities were sham."); Clipper Exxpress $v$ Rocky Mountain Motor Tariff Bureau, Inc., 690 F2d 1240, 1254 (9th Cir 1982) ("WWhile the success or failure of the protests is not singularly determinative of a party's intent, this Circuit regards such success or failure as indicative of a party's intent."); Handgards, 601 F2d at 996 ("[A] patentee's infringement suit is presumptively in good faith and ... can be rebutted only by clear and convincing evidence."). For commentary supporting this position, see Areeda and Hovenkamp, Antitrust Law at 21 (cited in note 56).

59 See text accompanying notes 106-15.

60 Courts generally engage in multiple determinations of "merit." These include deter- 
The economic-analysis version of the sham test was proposed in Grip-Pak, Inc. $v$ Illinois Tool Works, Inc. ${ }^{61}$ There Judge Posner presented a unique test by which predatory litigation, even if meritorious, could be a sham for purposes of Noerr. The prototype of this action is a case that is "not wholly groundless [but] would never be sued on for [its] own sake; the stakes, discounted by the probability of winning, would be too low to repay the investment in litigation." ${ }^{\prime 2}$ This decision, like all others divorcing the sham determination from the objective merits of the case, has been rejected by Professional Real Estate Investors. However, Grip-Pak alone provides a possible, although probably costly, alternative test grounded in measurable factors. Even so, the test is not truly objective; a complete accounting of both the costs and benefits of a suit would call for subjective valuations.

\section{Bill Johnson's Restaurants, Inc. $v$ NLRB.}

The Supreme Court ruled on sham suits in one other context prior to Professional Real Estate Investors when it decided Bill Johnson's Restaurants, Inc. $v$ NLRB. ${ }^{63}$ This decision is very significant both because it endorses the objective test for sham determinations and also because it demonstrates a situation other than an antitrust case in which the implications of the NoerrPennington doctrine may appropriately be applied.

Bill Johnson's began as an unfair labor practice action against a restaurant in which the plaintiff, a former employee, alleged that she was fired because of her attempts to organize a union at the restaurant. ${ }^{64}$ After the firing, some of the employ-

mining whether a claim has been stated under Rule 12(b)(6), whether summary judgment is appropriate, and, ultimately, who should win on the merits. This Comment argues that in the economic regulation context the objective test for sanctionability under Rule 11 is the most relevant inquiry. See text accompanying notes 106-15, 119-22. For an example of a court making both Rule 11 and sham determinations, see Harris Custom Builders, Inc. $v$ Hoffmeyer, 834 F Supp 256, 261-63 (N D Ill 1993).

61694 F2d 466 (7th Cir 1982).

62 Id at 472. The scenario that this opinion envisions is a case where "the plaintiff wants to hurt a competitor not by getting a judgment against him, which would be a proper objective, but just by the maintenance of the suit, regardless of its outcome." Id. In other words, it suggests weighing the net value of the suit against the expected costs of the suit. For an analysis of the Grip-Pak decision, see Hurwitz, 74 Georgetown L J at 10508 (cited in note 10); Handler and De Sevo, 6 Cardozo L Rev at 33-40 (cited in note 10); Lawrence A. Sullivan, Developments in the Noerr Doctrine, 56 Antitrust L J 361, 364 (1987). For an endorsement of the Grip-Pak approach, see Kintner and Bauer, 17 UC Davis $L$ Rey at $572-73$ (cited in note 49 ).

63 461 US 731 (1983).

64 Id at 733 . 
ees picketed the restaurant, and the owner responded with a lawsuit alleging that the picketers had harassed customers, blocked the entrance and exit to the restaurant, and created a threat to public safety. ${ }^{65}$ The fired employee then filed a second unfair labor practice charge based in part on the employer's lawsuit. ${ }^{66}$ The NLRB ordered the restaurant owner to withdraw the allegedly retaliatory lawsuit. ${ }^{67}$

The Court was thus faced with the question of whether the lawsuit was filed against the employee in retaliation for the earlier charges and, if so, whether this was an unfair labor practice. The Court held that "[t]he filing and prosecution of a well-founded lawsuit may not be enjoined as an unfair labor practice, even if it would not have been commenced but for the plaintiff's desire to retaliate against the defendant for exercising rights protected by the [National Labor Relations] Act." this case to the Noerr-Pennington line, especially California Motor Transport; in doing so it looked primarily to the First Amendment aspect of these cases. ${ }^{69}$

\section{Professional Real Estate Investors.}

In 1993, the Court finally settled on a standard for making sham determinations in the antitrust context, unequivocally showing its allegiance to objective determinations of intent in Professional Real Estate Investors. ${ }^{70}$ Unlike many of the decisions since Noerr, the Court primarily emphasized the aspect of Noerr that stressed the proper functioning of government.

Professional Real Estate Investors involved a copyright infringement suit by Columbia and other motion picture studios against a hotel that rented movie videodiscs for in-room viewing. ${ }^{71}$ The hotel filed an antitrust counterclaim charging that Columbia's suit was a sham and that it represented an attempt to restrain trade. ${ }^{72}$ After reviewing the entire Noerr-Pennington line of cases, the Court concluded that it was compelled "to reject a purely subjective definition of "sham," for "despite whatever

65 Id at 733-34.

${ }^{66}$ Id at 734-35.

${ }_{67}$ Id at 737 .

${ }_{68}$ Id at 743. Justice Brennan, the only Justice not joining the eight-member majority opinion, did not dispute this part of the holding. See id at 750 (Brennan concurring).

${ }^{69}$ Id at 741-44.

$70113 \mathrm{~S} \mathrm{Ct}$ at 1926.

71 Id at 1923.

72 Id at 1923-24. 
'superficial certainty' it might provide, a subjective standard would utterly fail to supply 'real intelligible guidance."'73

The Court then put forward a two-part definition of a sham. First, a sham suit would have to be "objectively baseless in the sense that no reasonable litigant could realistically expect success on the merits."74 Second, and less important for the purposes of this Comment, the baseless lawsuit would have to conceal "an attempt to interfere directly with the business relationships of a competitor." "Though the Court could have preserved some subjective element in the sham determination by adopting or modifying the "rebuttable presumption" approach or the Seventh Circuit's economic analysis, it chose to reject completely any subjective determination.

Applying its newly announced test, the Court borrowed language from Federal Rule of Civil Procedure 11, a source that it had not previously mentioned in the sham context. The Court found that the copyright action was "arguably 'warranted by existing law' or at the very least was based on an objectively 'good faith argument for the extension, modification, or reversal of existing law." "m6

The Court thus analogized the sham question to the Rule 11 inquiry. However, it acknowledged only one aspect of the Rule. The test failed to mention the second prong of Rule 11, which deals with suits "interposed for any improper purpose, such as to harass or to cause unnecessary delay or needless increase in the cost of litigation." 77

The Court's opinion contains three possible justifications for the objective test (beyond consistency with precedent and adherence to the original principles of Noerr) ${ }^{78}$ First, the Court extensively discussed the parallels between sham suits and the tort of malicious prosecution, concluding that, if this tort were successfully defended against, "a reasonable litigant in the defendant's position could realistically expect success on the merits." ${ }^{39}$ An objective determination will thus lead to greater foreseeability-both with respect to the outcomes of suits and anticipation of

73 Id at 1928, quoting Allied Tube, 486 US at $508 \mathrm{n} 10$.

74 Id at 1928.

75 Id at 1928, quoting Noerr, 365 US at 144.

76 Id at 1930-31, quoting FRCP 11.

77 FRCP 11.

78 These three justifications are discussed in greater detail below. See text accompanying notes 106-15.

$79113 \mathrm{~S}$ Ct at 1929-30. 
whether certain behavior is likely to lead to the filing of a suit by a competitor. Second, given the nature of antitrust liability, which includes treble damages, there are concerns about a possible chilling effect on meritorious litigation if Sherman Act liability may be imposed on objectively well-grounded suits. ${ }^{80}$ Finally, the Court appeared to be concerned about the general line-drawing problems of subjective determinations and the potential inconsistency they engender. ${ }^{81}$

\section{The CuRRENT APPLication OF RULE 11 IN THE Federal CoURTS}

In order to appreciate the implications of the NoerrPennington doctrine, particularly since Professional Real Estate Investors has now drawn a parallel between determining shams and sanctioning parties under rules of procedure, it is necessary to examine the current state of Rule 11 jurisprudence. This Section discusses the two prongs of Rule 11 and the ways in which courts have imposed sanctions under each of them. It also addresses the changes to Rule 11 that became effective on December 1, 1993.

\section{A. The Two Prongs of Rule 11}

Rule 11, as worded when Professional Real Estate Investors was decided, provided that any "pleading, motion, and other paper of a party" must be

to the best of the signer's knowledge, information, and belief formed after reasonable inquiry ... well grounded in fact and [ ] warranted by existing law or a good faith argument for the extension, modification, or reversal of existing law, and ... interposed for any improper purpose, such as to

${ }^{80}$ See Comment, 74 Iowa L Rev at 283-84 (cited in note 56); Hurwitz, 74 Georgetown $\mathrm{L} J$ at 105 (cited in note 10); Handler and De Sevo, 6 Cardozo L Rev at 13, 30-32 (cited in note 10).

There is also a concern about chilling constitutionally protected petitioning activity. This could occur to the extent that the Noerr-Pennington doctrine defines the scope of First Amendment protection. In other words, if "non-sham" is equivalent to "constitutionally protected," then discouraging non-sham suits would restrain the legitimate uses of the right to petition. This is perhaps yet another reason for favoring objective determinations. See Bien, 16 USF L Rev at 86 (cited in note 38) (arguing that uncertainty due to the lack of a definite rule has a chilling effect); Balmer, 29 Buff L Rev at 60-62 (cited in note 15) (cautioning courts to "err on the side of protecting first amendment values").

$81113 \mathrm{~S}$ Ct at 1927. 
harass or to cause unnecessary delay or needless increase in the cost of litigation. ${ }^{82}$

The rule further required the courts to "impose ... an appropriate sanction" for violations. ${ }^{83}$

On its face, Rule 11 appears to have two parts that trigger sanctions. The courts of appeals have, in fact, acknowledged the existence of two prongs: the objective prong, which sanctions suits lacking a reasonable basis in fact and law, and the subjective prong, under which a suit brought under an improper intent will be sanctioned. These are known, respectively, as the "frivolousness clause" and the "improper purpose clause."184 There is, however, some dispute about the specific requirements of each prong.

Before going into the details of Rule 11 interpretation, it is necessary to address the relevant recent amendments to Rule $11 .^{85}$ The new version of the rule separates the two prongs of the old rule into different subsections, thus highlighting the fact that the rule may be violated in two ways. ${ }^{86}$ The relevant parts of the second section, entitled "Representations to Court" are:

82 FRCP 11 (1992).

$83 \mathrm{Id}$.

84 Zaldivar $v$ City of Los Angeles, 780 F2d 823, 830-31 (9th Cir 1986), abrogated on other grounds by Cooter \& Gell v Hartmarx Corp., 496 US 384 (1990). See also Herron $v$ Jupiter Transportation Co., 858 F2d 332, 335 (6th Cir 1988); Brown v Federation of State Medical Boards, 830 F2d 1429, 1435-36 (7th Cir 1987), abrogated on other grounds by Mars Steel Corp. $v$ Continental Bank N.A., 880 F2d 928 (7th Cir 1989); Mitford v Marsh, 972 F2d 1341, 1992 US App LEXIS 30070, *9-10 (9th Cir) (table); Adam H. Bloomenstein, Developing Standards for the Imposition of Sanctions Under Rule 11 of the Federal Rules of Civil Procedure, 21 Akron L Rev 289, 296-305 (1988).

Some courts have found three prongs by dividing the frivolousness clause into a grounded in fact prong and a warranted by existing law prong. See Westmoreland $v C B S$, Inc., 770 F2d 1168, 1174 (DC Cir 1985); Kunstler v Britt, 914 F2d 505, 514-18 (4th Cir 1990); Thomas v Capital Security Services, Inc., 812 F2d 984, 988 (5th Cir 1987). These courts distinguish these two objective prongs from the subjective improper purpose clause in the same way as courts using a two-prong analysis. Since all these courts make the same objective/subjective distinction, their treatment of Rule 11 is identical for the purposes of this Comment.

85 The amendments to the Federal Rules of Civil Procedure went into effect automatically on December 1, 1993 when Congress adjourned without adopting proposed changes. See Mary Hull and Ann Pelham, New Federal Rules Catch Judges, Lawyers Off-Guard, Texas Lawyer 1 (Dec 6, 1993). At any rate, the proposed changes, which Congress may yet pass, focus on discovery rules rather than on Rule 11. See Randall Samborn, New Discovery Rules Take Effect; Bill to Stop Change Dies, Natl L J 3 (Dec 6, 1993). Congressional action on Rule 11 faltered earlier. See House Votes to Block Change in Federal Discovery Rule, Liability Week (Nov 8, 1993).

${ }^{86}$ The new version also contains two other provisions, requiring that "allegations and other factual contentions have evidentiary support" and that "denials of factual contentions are warranted on the evidence." FRCP 11(b)(3)-(4). 
By presenting to the court ... a pleading, written motion, or other paper, an attorney or unrepresented party is certifying that...

(1) it is not being presented for any improper purpose, such as to harass or to cause unnecessary delay or needless increase in the cost of litigation; [and that]

(2) the claims, defenses, and other legal contentions therein are warranted by existing law or by a nonfrivolous argument for the extension, modification, or reversal of existing law or the establishment of new law. ${ }^{87}$

This change is unlikely to affect substantially the analysis of this Comment.

The provision of the rule regarding sanctions was also changed. Whereas the old rule provided that a court "shall impose ... an appropriate sanction," 88 the new version of the rule states that "the court may... impose an appropriate sanction." ${ }^{89}$ This additional element of discretion may not change the practical effects of the rule very much since the "appropriate sanction" language in both rules is very malleable anyway. ${ }^{90}$ However, to the extent that this change does introduce more overt discretion to Rule 11 sanctions, it recognizes that sanctions may not be appropriate in all contexts. This Comment argues that sanctions are not appropriate in the antitrust context absent a violation of the objective prong of the rule.

\section{B. Sanctions Under Rule 11}

Current Rule 11 jurisprudence is still an appropriate point of departure, especially since Professional Real Estate Investors now specifically tracks the objective, "frivolousness" inquiry called for by subsection (b)(2) of the Rule, and does not mention the subjec-

87 FRCP 11(b).

88 FRCP 11 (1992).

${ }^{89}$ FRCP 11(c) (emphasis added).

s0 These changes, along with a newly-adopted safe harbor and new restrictions on cost-shifting, may, however, lead to a decline in the use of Rule 11. See Robert E. Bartkus, Rule 11's New Teeth Have a Broader Bite, NJ I J 11 (Dec 20, 1993); Robert J. Giuffra, Jr., Federal Rules of Civil Procedure: 1993 Amendments, NY L J 1 (May 10, 1993); Marcia M. McBrien, Magistrate Judge Highlights Changes to Federal Rules, Mich Lawyers Weekly 1A (Oct 18, 1993); Linda S. Mullenix, Civil Rule Revisions a Mixed Bag, Natl L J S14 (Aug 23, 1993); Carl Tobias, New Rule in Need of Trial Run, Natl L J 15 (June 21, 1993). 
tive or "improper purpose" inquiry contained in subsection (b)(1) of the Rule.

There has been much more convergence in courts' views of the nature of the frivolousness clause than of the improper purpose clause of Rule 11. The frivolousness inquiry has almost always been examined objectively: courts have inquired only as to whether the motion or pleading was objectively valueless, without looking at the intent of the party submitting the argument. ${ }^{91}$ This consensus among the circuits-reinforced by the 1993 amendments $^{92}$ and embraced by Professional Real Estate Investors-means that an objectively frivolous suit is always sanctionable under Rule 11, and is a sham if it directly interferes with the business relationships of a competitor.

The improper purpose standard, on the other hand, has been applied in a number of different ways. It appears from the language of the rule that the courts must at least undertake to approximate, if not to reconstruct, the intent of the filing party. This, of course, is to some extent what the Noerr-Pennington cases are all about: California Motor Transport, for instance, spoke of "a purpose to deprive the competitors of meaningful access to the agencies and courts." ${ }^{.93}$ Professional Real Estate Investors can thus be seen as a decision declining to inquire into the parties' intent, substituting an objective baselessness test instead.

With respect to Rule 11, however, the appellate courts have taken both tacks. Some have applied an objective baselessness standard for finding improper purpose clause violations, while others have focused on subjective intent. Even those courts ap-

91 See Lancellotti v Fay, 909 F2d 15, 19 (1st Cir 1990) ("Put bluntly, a pure heart no longer excuses an empty head."); Eastway Construction Corp. $v$ City of New York, 762 F2d 243, 253 (2d Cir 1985) ("Simply put, subjective good faith no longer provides the safe harbor it once did."); Stevens v Lawyers Mutual Liability Insurance Co., 789 F2d 1056, 1060 (4th Cir 1986); INVST Financial Group, Inc. $v$ Chem-Nuclear Systems, Inc., 815 F2d 391, 401 (6th Cir 1987); Rodgers v Lincoln Towing Service, Inc., 596 F Supp 13, 28 (N D IIl 1984); Zaldivar, 780 F2d at 829; Golden Eagle Distributing Corp. v Burroughs Corp., 801 F2d 1531, 1537-38 (9th Cir 1986). See also Bloomenstein, 21 Akron L Rev at 294-96 (cited in note 84); Edward D. Cavanagh, Developing Standards Under Amended Rule 11 of the Federal Rules of Civil Procedure, 14 Hofstra L Rev 499, 525-30 (1986); William W. Schwarzer, Rule 11 Revisited, 101 Harv L Rev 1013, 1016 (1988).

${ }^{92}$ See Advisory Committee Notes to 1993 Amendments to FRCP 11. For example, the Committee observed that "[a]rguments for extensions, modifications, or reversals of existing law ... do not violate subdivision (b)(2) provided they are 'nonfrivolous.' This establishes an objective standard intended to eliminate any 'empty-head pure-heart' justification for patently frivolous arguments." Id.

${ }_{93} 404$ US at 512 (emphasis added). 
plying the objective baselessness standard have taken divergent approaches. Some merely hold that a case's lack of merit is itself sanctionable harassment under the improper purpose clause. ${ }^{94}$ This approach, however, essentially just uses one part of Rule 11 to satisfy the other part. The fact that the two parts must be linked does not show what sort of test should be used in cases where only one prong, improper intent, comes into question. Other courts have gone further and applied an objective test of bad faith. ${ }^{95}$ These courts, of course, are unlikely to be affected by the Professional Real Estate Investors decision because they already use the same test for Rule 11 sanctions that is now required for sham determinations. Thus, there will not be cases that meet one test while failing the other.

Other jurisdictions, however, favor subjective determinations of sanctionability. Some courts have held cases sanctionable even when the suits were objectively meritorious or at least adequately based in fact and law. ${ }^{96}$ As this Comment argues, these cases are likely inconsistent with the sham test laid down in Professional Real Estate Investors.

\section{THE PROFESSTONAL REAL ESTATE INVESTORS-RULE 11} TENSION IN ANTITRUST LITIGATION

The Supreme Court linked the sham standard announced in Professional Real Estate Investors very closely to a Rule 11-like test of objective baselessness. Yet the Court accounted for only one part of Rule 11 in its decision. While this makes the sham test very convenient for the courts, it creates a potential problem in antitrust contexts, depending on a court's approach to Rule 11.

94 See Markwell $v$ County of Bexar, 878 F2d 899, 903 (5th Cir 1989); Mitford, 972 F2d 1341, 1992 US App LEXIS 30070, *11.

${ }_{95}$ See Westlake North Property Owners Association v City of Thousand Oaks, 915 F2d 1301, 1307 (9th Cir 1990) (holding a complaint with an objectively reasonable basis in law was not frivolous, and therefore not sanctionable under "improper purpose" clause); Lieb $v$ Topstone Industries, Inc., 788 F2d 151, 157 (3d Cir 1986) ("The pleader may not escape liability because he did not intend to bring about additional delay or expense."); Fahrenz $v$ Meadow Farm Partnership, 850 F2d 207, 210 (4th Cir 1988) (Courts must judge conduct "under an objective standard of reasonableness rather than assessing subjective intent."); Di Silvestro $v$ United States, 767 F2d 30, 32-33 (2d Cir 1985) (finding bad intent in the filing of a claim barred by res judicata and court injunction). See also Bloomenstein, 21 Akron L Rev at 318-20 (cited in note 84).

${ }^{96}$ See Pathe Computer Control Systems Corp. v Kinmont Industries, Inc., 955 F2d 94, 97 (1st Cir 1992); Aetna Life Insurance Co. v Alla Medical Services, Inc., 855 F2d 1470, 1476-77 (9th Cir 1988); Ballentine v Taco Bell Corp., 135 FRD 117, 122 (E D NC 1991). 


\section{A. The Problem: Non-sham Suits Brought to Harass or Delay}

Imagine a case in which a claim, whether a complaint, counterclaim, or other pleading, filed by X Corp against its competitor, Y Corp, was objectively based in law, yet filed for the purpose of harassing or interfering with $Y$ Corp. In response, $Y$ Corp then alleges that $\mathrm{X}$ Corp's action is a violation of the antitrust laws and not entitled to immunity under the Noerr-Pennington doctrine because it is a sham. This scenario is, in fact, very similar to the situation facing the Court in Professional Real Estate Investors, except that it was never alleged that Columbia's case "involved misrepresentations" or lacked "probable cause." Instead, it was merely alleged that Columbia "did not honestly believe that the infringement claim was meritorious." ${ }^{\prime \prime}$ Given the Court's holding in Professional Real Estate Investors, however, it is inevitable that future litigants will try to fit their allegations of sham within the more narrow exception by alleging baselessness rather than wrongful intent. ${ }^{98}$ If $\mathrm{Y}$ Corp fails to show that X Corp's suit is a sham, there may be a situation in which $X$ Corp will be exempt from antitrust liability under the Noerr-Pennington doctrine yet still be violating the improper purpose prong of Rule 11 under a subjective-intent analysis. ${ }^{99}$

Such an outcome is problematic in two respects. First, it results in the same lawsuit being legitimate in one sense, since it is not a sham, while illegitimate in another, if it is found to be harassing or unduly dilatory. While this may not have occurred in the past, Professional Real Estate Investors tied the two tests so closely together that such an outcome is now a real and troubling possibility. Because the effect of both tests is the same--they determine which suits should not have been filed-it makes'little sense to sanction suits inconsistently.

97 Professional Real Estate Investors, $113 \mathrm{~S} \mathrm{Ct}$ at 1925. Had there been actual fraud, the petitioning activity would not have been protected-but not because of any bad intent prong to the sham exception. It would instead have fallen under the analysis of Walker Process, 382 US at 173-74, which makes fraud and other illegal acts during petitioning a valid basis for antitrust liability. See note 38 .

${ }_{98}$ See, for example, Liberty Lake Investments, Inc. v Magnuson, 12 F3d 155, 1993 US App LEXIS 32686, *5-6 (9th Cir).

99 This assumes that "to harass," as used in Rule 11, can be equated with a purpose "to interfere directly with the business relationships," as required by the original definition of a sham. See FRCP 11(b)(1); Noerr, 365 US at 144. This is, however, an easy case to make, especially given the interchangeability with which the courts have used these and similar terms in the Noerr-Pennington cases. See Professional Real Estate Investors, $113 \mathrm{~S}$ Ct at 1929; California Motor Transport, 404 US at 512-13; Westmac, 797 F2d at 318; Burlington Northern, 822 F2d at 528; McGuire Oil, 958 F2d at 1559-60. 
More importantly, compelling rationales suggest that the sham determination should be limited to an objective inquiry in the first place. To the extent that the justifications for an objective test of shams are valid, they should apply equally to the inquiry required by Rule $11 .{ }^{100}$ Since Noerr and its exception have effectively transformed antitrust law into a mechanism for policing access to government bodies, including the courts, ${ }^{101}$ the same policy considerations should underlie liability determinations in Rule 11 situations, since this rule is also an instrument for policing conduct before and access to the courts. Any application of Rule 11 which conflicts with the objective sham determination would undermine the policies behind the adoption of this test for policing litigation between parties in antitrust cases. Furthermore, a conflicting Rule 11 standard may discourage parties from pursuing claims that are deemed permissible in the antitrust context for fear of violating a standard that is not specifically tailored to their situation.

\section{B. Limiting the Application of Rule 11 in Antitrust Litigation}

To restore consistency to the policing of litigation, either the standard for determining shams or the standard for imposing Rule 11 sanctions should be modified. While this Comment argues that an objective test is appropriate whenever the government, and especially a court, acts as an economic regulator, Professional Real Estate Investors makes an objective standard appropriate, at a minimum, in the antitrust context. Because the Court has clearly articulated the test for the sham exception, and because the objective test is supported by valid policy considerations, Rule 11 should give way. Both the interest in procedural consistency and substantive policy considerations support limiting Rule 11 inquiries in the antitrust context to objective determinations of merit or the reasonable chance of success. In effect, the objective Rule 11 analysis presented in Professional Real Estate Investors should be the only test used to distinguish permissible from sanctionable claims.

As an initial matter, such a modification of Rule 11 will not be overly problematic. Rule 11 is a general policing mechanism,

100 See text accompanying notes 77-81, 106-15.

101 By opening the door to antitrust liability, the sham exception has the practical effect of deciding what suits are properly brought and discouraging those that are not. See Comment, 74 Iowa L Rev at 282-84 (cited in note 56); Fischel, $45 \mathrm{U}$ Chi L Rev at 94-96 (cited in note 10); Handler and De Sevo, 6 Cardozo L Rev at 13 (cited in note 10). 
but it is confronted here with context-specific reasons for alteration. This argument is analogous to the preference for specific provisions over general ones in statutory construction. ${ }^{102}$ Professional Real Estate Investors should be read as a specific directive to police litigation in the antitrust context with an objective baselessness inquiry. This ought to trump any other concerns about policing litigation in general. Other concerns are at stake, of course: parties must not be allowed to misuse the judicial system, as this would compromise respect for the courts and undermine the integrity of the judicial process. But fraud or perjury are still punishable notwithstanding this proposal, both with antitrust liability ${ }^{103}$ and with other mechanisms that this Comment does not suggest altering, such as contempt sanctions or criminal liability. Indeed, a more consistent and context-sensitive approach to sanctioning ought to increase confidence in the judicial system, especially for antitrust litigants.

This argument is even stronger if Professional Real Estate Investors is viewed as an extension of the proper-functioning-ofgovernment concern of Noerr. The Professional Real Estate Investors opinions did, in fact, stress the need to ensure the proper functioning of government institutions over the First Amendment concerns that were more prominent in California Motor Transport. ${ }^{104}$ In addition to quoting Noerr to support an objective test for determining shams, the Professional Real Estate Investors Court stressed that it had, in Noerr, "reasoned that the Sherman Act does not punish 'political activity' through which 'the people . . . freely inform the government of their wishes."'105

The "function" of government in the antitrust context is the Court acting as economic regulator, and the efficiency of that function is generally controlled by mechanisms such as Rule 11 or liability for such things as the filing of sham suits. Professional Real Estate Investors is really a specific directive that courts ought to use an objective, outcome-oriented analysis of intent whenever they act as economic regulators.

${ }^{102}$ See Karl N. Llewellyn, Remarks on the Theory of Appellate Decision and the Rules or Canons About How Statutes Are to Be Construed, 3 Vand L Rev 395, 405 (1950); Cass R. Sunstein, After the Rights Revolution 151 (Harvard, 1990).

103 See note 38.

104 See text accompanying notes 30-31.

${ }_{105}$ Professional Real Estate Investors, $113 \mathrm{~S} \mathrm{Ct}$ at 1926, quoting Noerr, 365 US at 137. In relying on this part of Noerr, the Court implicitly rejected the view, advanced by some commentators, that the protection of petitioning activity was the principal concern of the Noerr line of cases. See Fischel, $45 \mathrm{U}$ Chi L Rev at 82-83 (cited in note 10); Handler and De Sevo, 6 Cardozo L Rev at 3-5, 12 (cited in note 10). 
C. The Rationales Underlying an Objective Determination of Shams

The arguments favoring an objective regulation of suits raising antitrust implications have already been sketched out. ${ }^{106}$ In addition to the benefit of consistency between sham determinations and Rule 11 sanctions, there are three reasons to prefer the Professional Real Estate Investors test to the subjective intent-Rule 11 test favored by some of the circuits.

\section{Efficiency of the courts.}

Efficiency concerns support an objective test for determining whether a party should be sanctioned under Rule 11. In antitrust actions, a subjective test of a lawsuit's propriety would often force a court to evaluate the intent of a large corporation, since these suits generally involve corporations. Corporations are unlikely to exhibit any consistent institutional intent, because they are large, have many individual speakers, actors, and decision makers, and have many motivations for any action, whether litigation or otherwise. ${ }^{107}$ Judge Posner has noted that, because of these factors, "[i]t is extraordinarily difficult to ascertain the intent of a large corporation by the methods of litigation," and that "[a]ny doctrine that relies upon proof of intent is going to be applied erratically at best." 108 Furthermore, it is very easy for the side alleging the violation to present some evidence of an intent to harass since the opposing parties in all of these cases are, after all, business competitors. ${ }^{109}$

As desirable as objective tests may be in general, the argument for them is even stronger in the antitrust-litigation context.

106 See text accompanying notes 79-81.

107 Public choice theory analogously holds that "intent" is an incoherent concept when applied to multi-member bodies and that such bodies' priorities "cycle" depending upon who controls the agenda. See, for example, Daniel A. Farber and Philip P. Frickey, Law and Public Choice: A Critical Introduction 40-42 (Chicago, 1991).

${ }_{108}$ Richard A. Posner, Antitrust Law: An Economic Perspective 189-90 (Chicago, 1976) (discussing the problems that arise when predatory pricing is defined in terms of the seller's intent). See also Areeda and Hovenkamp, Antitrust Law at 17 (cited in note 56) (subjective inquiry is "hazardous and of doubtful utility" in most cases); Comment, 74 Iowa L Rev at 281-82 (cited in note 56); William G. Shepherd, Assessing "Predatory" Actions by Market Shares and Selectivity, 31 Antitrust Bull 1, 17 (1986). But see Bien, 16 USF L Rev at 56-57 (cited in note 38).

Courts have also acknowledged this difficulty in antitrust cases. See, for example, Grip-Pak, 694 F2d at 472; Greenwood Utilities Commission v Mississippi Power Co., 751 F2d 1484, 1498 \& n 9 (5th Cir 1985); Omni Outdoor Advertising, 499 US at 375, 383.

109 See Comment, 74 Iowa $L$ Rev at 284-85 (cited in note 56). 
The choice here is not merely between reconstruction of a party's intent and an objective determination of the potential merit of a claim on its face. The question is whether it makes sense to add the subjective inquiry to the objective one that the Supreme Court has now required in these cases. So long as there is adequate reason to believe that the objective test will yield acceptable outcomes, it would be wasteful to engage in a subjective inquiry as well. ${ }^{110}$

2. Discouraging meritorious claims.

A subjective inquiry might also have a chilling effect on meritorious litigation. This problem has been noted in the context of a subjective approach to sham determinations, where exposure to antitrust liability, including treble damages, tends to magnify this effect. ${ }^{111}$ Rule 11 penalties are not likely to be as severe as potential antitrust liability, but some chilling effect would still occur. This is more true in antitrust cases than in other types of cases because of the relative ease with which harassment can be alleged. ${ }^{112}$ This factor produces more uncertainty for parties contemplating lawsuits, and hence might deter some suits that would be filed if the parties could foresee how their actions would be judged.

\section{Expectations of the parties.}

The final advantage of an objective test is that it is more likely to coincide with all parties' reasonable expectations. An objective test is simply more predictable. ${ }^{113}$ The Supreme Court even alluded to this argument in Professional Real Estate Investors itself. ${ }^{114}$ Predictability will help potential plaintiffs determine their likely exposure to sanctions or antitrust liability, and will help potential defendants better anticipate lawsuits and tailor their actions accordingly.

110 Two commentators have also noted that a system in which every sham determination turned on the intent of the party would necessitate a jury decision in every case, another costly enterprise for the courts. Handler and De Sevo, 6 Cardozo L Rev at 39-40 (cited in note 10).

111 See id at 39; Hurwitz, 74 Georgetown L J at 105 (cited in note 10); Comment, 74 Iowa $\mathrm{L}$ Rev at 282-84 (cited in note 56); Balmer, 29 Buff L Rev at 68 (cited in note 15); Blecher and Bennett, 26 Mercer $L$ Rev at $479-81$ (cited in note 9).

112 See text accompanying note 109.

113 Comment, 74 Iowa L Rev at 282-84.

$11113 \mathrm{~S} \mathrm{Ct}$ at 1930. 
Noer-Pennington suits often arise from non-antitrust matters-for example, copyright, trademark, or patent infringement, violation of fiduciary duties, or other tort or contract actions-where the antitrust allegations are raised as a counterclaim or affirmative defense. ${ }^{115}$ Parties will naturally want to know the likely future consequences of their business decisions. To judge, even roughly, the possibility of a competitor filing a lawsuit, parties must assess the disincentives to filing suit that the other party faces. These disincentives include potential antitrust liability if the suit is found to be a sham, as well as the threat of Rule 11 sanctions. If the parties can be sure that a court will impose such liability on the basis of objective determinations of merit rather than on the basis of subjective inquiries, the parties are far more likely to be able to predict a court's likely decision. In turn, this helps parties make accurate business decisions ex ante.

\section{The Grip-Pak Alternative}

The Grip-Pak decision ${ }^{116}$ presents a possible alternative to the approach recommended in this Comment. The rebuttable presumption that a successful lawsuit is not a sham ${ }^{117}$ could be combined with the Seventh Circuit's extension of liability to predatory litigation. ${ }^{118}$ This hybrid approach could claim to be an alternative objective test, one that weighs the costs and benefits to a party-or a reasonable litigant in the same situation-of bringing a suit.

This approach, however, would not solve the problems created by purely subjective tests because the alternative test would itself depend heavily on subjective assessments of the costs and benefits of the litigation in question. The determination of whether a party had in fact brought a suit as a sham would depend on the party's own valuations of various methods and outcomes in a particular suit. This approach, although most likely to lead to the results desired by the Seventh Circuit, still requires an analysis of a complex entity's decision-making process, which is one of the major problems with a subjective approach.

115 See Handler and De Sevo, 6 Cardozo L Rev at 26-28 (cited in note 10).

116 See text accompanying notes 61-62.

117 See, for example, Areeda and Hovenkamp, Antitrust Law at 21 (cited in note 56).

118 Grip-Pak, 694 F2d at 472. See also text accompanying notes 61-62. For commentary on this decision, see note 62 . 
Alternatively, if the test is simplified to require only a comparison of the costs of litigation and the damages sought, it fails to include other legitimate short- and long-term benefits of winning a suit, such as deterring future patent infringements. This test would result in far too many findings of sham suits. An attempt to measure these benefits objectively could well be prohibitively difficult, given the information that would be necessary to make such determinations. In any case, the attempt would certainly be much less efficient-without necessarily being any more accurate-than an objective baselessness inquiry.

\section{BROADER IMPLICATIONS OF THE OBJECTIVE BASELESSNESS} TEST

An inevitable question at this juncture is whether the objective test, which appears to work very well in the antitrust context, should be extended to govern Rule 11 considerations in other areas of the law. The answer to this question depends to a significant extent on which of Noerr's two rationales served as the basis for Professional Real Estate Investors.

\section{A. First Amendment Right to Petition}

This Comment has argued that Professional Real Estate Investors was based on Noerr's proper-functioning-of-government rationale. ${ }^{119}$ If, however, Professional Real Estate Investors is a decision about the First Amendment right to petition, which many writers have argued is the true significance of the NoerrPennington cases, ${ }^{120}$ then its impact on Rule 11 jurisprudence will be very far-reaching. Without pursuing this argument at length, this Comment sketches its outlines.

Based on a right-to-petition reading of Professional Real Estate Investors, it could be argued that the Noerr-Pennington doctrine now protects all petitioning, at least before courts, that is objectively well-based in fact and law. Such an interpretation would mean that lawsuits could not be policed beyond an objective baselessness standard, since a party would have a right to petition so long as that petition had an objective basis. This in-

119 See text accompanying notes 102-04.

120 See Fischel, 45 U Chi L Rev at 94-104 (cited in note 10); Note, The Sham Exception to the Noerr-Pennington Doctrine: A Commercial Speech Interpretation, 49 Brooklyn L Rev 573, 594-603 (1983); Balmer, 29 Buff L Rev at 61 (cited in note 15). For an overview of the two rationales, see Handler and De Sevo, 6 Cardozo L Rev at 3-7; Hurwitz, 74 Georgetown $\mathrm{L} \mathrm{J}$ at 78-80 (cited in note 10). 
terpretation would be especially true if the suit was ultimately found to be meritorious. The problem then would no longer be chilling meritorious lawsuits, but chilling constitutionally protected petitioning. ${ }^{121}$ Because an overly broad definition of "sham" would threaten the valid exercise of First Amendment rights at risk, any greater scope of sanctions would be prohibited. ${ }^{122}$

This logic would have to be extended to other areas of the law as well, including Rule 11. It implies that the objective approach test for applying the improper purpose clause is constitutionally mandated. At least two other areas of the law would also be affected: the common law torts of malicious prosecution and abuse of process. The Court in Professional Real Estate Investors noted the similarity between these torts and the sham determination, ${ }^{123}$ as have other courts and commentators. ${ }^{124}$ For the same reason that Rule 11 would have to be modified, the requirements for these torts would have to be modified in any jurisdictions that relied on subjective determinations of bad faith or improper purposes.

Yet given the Court's emphasis on the proper-functioning-ofgovernment rationale for Noerr over the First Amendment issues, it seems improbable that Professional Real Estate Investors was meant to be a revision of an entire aspect of First Amendment jurisprudence. A uniform standard of protection for objectively plausible claims may be a logical extension of the Court's holding, but it certainly is not mandated. The Noerr-Pennington cases do, however, provide a guide to the applicability of the objective baselessness standard. Such protection makes most sense, and therefore may even be required, when a court is playing the role of economic regulator. This extension of Professional Real Estate Investors reflects concerns about chilling petitioning activity that may be protected by the First Amendment but does not purport

121 See Balmer, 29 Buff L Rev at 60-62 (cited in note 15); Bien, 16 USF L Rev at 86 (cited in note 38); Handler and De Sevo, 6 Cardozo L Rev at 13, 39 (cited in note 10); Note, 11 Hastings Const L Q at 332-36 (cited in note 38); Note, 86 Harv L Rev at 735 (cited in note 15).

122 Recently, one court held something nearly this broad. See Whelan v Abell, $827 \mathrm{~F}$ Supp 801, 803 (D DC 1993), dismissed 1993 WL 410900 (DC Cir) ("This Court can find no basis to so narrowly limit the doctrine. Certainly, if a person has a protected right to bring an objectively-based antitrust claim against a competitor, the same protection must be afforded to others who bring other such objectively-based claims and allegations before a government agency or court."). See also Computer Associates International, Inc. $v$ American Fundware, Inc., 831 F Supp 1516, 1523 (D Colo 1993).

$123113 \mathrm{~S} \mathrm{Ct}$ at 1929.

124 See Grip-Pak, 694 F2d at 470-71; Whelan, 827 F Supp at 804. See generally Note, 86 Harv L Rev 715 (cited in note 15). 
to revise existing First Amendment law beyond the economicregulator context.

\section{B. Extending the Proper-Functioning-of-Government Logic}

If it is true that Professional Real Estate Investors rests on the proper-functioning-of-government basis of Noerr, then the logic of the case should be extended to functionally similar proceedings. Such proceedings would include cases that, like antitrust cases, are marked by particularly high subjective inquiry costs, the need for predictability, and the fear of imposing a chilling effect on meritorious suits through excessive deterrence. A wide range of cases share these characteristics-especially the latter two. Extending the logic of Professional Real Estate Investors to functionally similar proceedings would thus still call for a broad application of the principle of objective determination of non-meritorious litigation.

Three factors support the application of an objective test for sham suits in the antitrust context: (1) the fact that courts perform an explicitly economic regulatory function in antitrust cases; (2) the fact that parties to antitrust litigation are usually competitors not only in litigation but also outside the courtroom, which makes some harassing intent especially easy to infer; and (3) the fact that, typically, at least one of the parties is a large enterprise or a corporation.

The courts' economic regulatory function is more reliably carried out through objective tests of intent. ${ }^{125}$ This is true because objective inquiries are more predictable, which better allows parties to conform their behavior, and because the marketplace itself is outcome-oriented, allocating goods by a mechanism-the price system-that is indifferent to intent. It makes sense, then, that bad results-in this case meritless suits or counterclaims-be punished, and not bad intent.

That parties deal repeatedly with one another both inside and outside the courtroom also has an impact on the reliability of a subjective standard. In any case where the parties are competitors, allegations of subjective bad intent are easier to make and corroborate. ${ }^{126}$ Thus, the uncertainty of determining sanctions is extended to more cases, and the chilling effect of this approach is

125 See text accompanying notes 107-15.

125 See text accompanying note 109. Antitrust is, of course, the prototypical case, as the parties will always be economic competitors. 
magnified whenever the court undertakes a subjective inquiry. Finally, in cases involving large enterprises, as opposed to individuals, subjective determinations of intent are more difficult. ${ }^{127}$

Unfair labor practice litigation (to which the Supreme Court analogized the Noerr doctrine) provides an example of a nonantitrust area where these factors are present. ${ }^{128}$ In these cases, the courts help regulate the collective bargaining process between businesses and their employees or their employees' unions. These courts function much like economic regulators and the parties certainly deal with each other repeatedly in an adversarial or competitive manner. Both the businesses and the unions are also large entities with multiple decision makers, making determinations of an overall subjective intent very difficult. Many other situations would also be analogous, such as breach of contract claims between corporate entities. ${ }^{129}$ In cases bearing such a resemblance to antitrust cases, courts should follow the reasoning of Professional Real Estate Investors and impose Rule 11 sanctions only upon a showing that a party's filing was objectively baseless.

\section{CONCLUSION}

Professional Real Estate Investors holds that whether a lawsuit constitutes a sham for Noerr-Pennington purposes depends solely on whether it is objectively baseless. This decision, however, has an impact on areas of the law beyond the NoerrPennington doctrine. The extent to which Professional Real Estate Investors affects other mechanisms that police access to the courts depends on whether it is grounded in the right-to-petition or the proper-functioning-of-government rationale of the original Noerr case.

If it extends the right-to-petition analysis of Noerr, then Professional Real Estate Investors effectively mandates an objective test of intent for all sanctioning mechanisms that police access to the courts-not only Rule 11, but common law torts such as malicious prosecution and abuse of process as well. While it might seem extreme to ascribe such an effect to the case, Pro-

${ }_{127}$ See text accompanying notes 107-09.

128 See Bill Johnson's Restaurants, 461 US at 741-44.

129 The Professional Real Estate Investors analysis was, in fact, recently extended to such a case. See Computer Associates International, 831 F Supp at 1521-23 (extending Noerr-Pennington protection to an "unfair competition" counterclaim to a breach of contract suit). 
fessional Real Estate Investors at a minimum creates a tension with Rule 11 in antitrust law and related areas. To the extent that an objective test is desirable due to considerations of efficiency, predictability, and avoiding a chilling effect on meritorious litigation, the reasoning of Professional Real Estate Investors should be adopted for other Rule 11 proceedings that have functionally similar elements. 
. 